\title{
Early modern extraterritoriality, diplomacy, and the transition to capitalism
}

\section{Maïa Pal1}

\begin{abstract}
:
This chapter revisits the early modern history of extraterritoriality through the angle of the social origins of diplomatic actors and the transition to agrarian capitalism in England. Doing so breaks down the classic elitist and institutionally narrow history of diplomacy, which equates extraterritoriality with ambassadorial immunity and the emergence of embassy chapels in the sixteenth and seventeenth centuries. By focusing on class and social structures, this chapter provides a more 'entangled' and contested - rather than linear and homogeneous - history of extraterritoriality and its ambassadorial origins in the early modern period. Its analysis reveals important divergences between France and England in regard to their strategies of territorialisation and use of diplomats linked to their respective social property relations. For example, the rising gentry in England and the use of 'MP diplomats' is linked to the emergence of agrarian capitalism, while the rise of the aristocracy in diplomatic posts and the mix of personal and territorial sovereignty in French embassies under Louis XIV display the regime's tactics of collaboration. Therefore, new historical and sociological avenues to research early modern extraterritoriality are opened up so as to recover how various doctrines of extraterritoriality were shaped by various social groups and different jurisdictional strategies.
\end{abstract}

Key words: diplomacy, ambassadors, immunity, agrarian capitalism, social property relations, aristocracy, gentry, personal sovereignty, territorial sovereignty, MP diplomats, Political Marxism, embassy chapels

\section{Introduction}

Scholarly approaches in the related fields of diplomacy and the history of international relations (IR) associate extraterritoriality with the emergence of both permanent embassies in the fifteenth and sixteenth centuries and ambassadorial immunity in the sixteenth century.2 More broadly, this literature is focused on intellectual history, the origins and development of state institutions, and links between leading diplomats and the classical canon of legal theory. An ongoing problem with this literature is that it tends to ignore the socio-economic causes and implications of shifts in diplomatic practice and personnel in the context of broader shifts in international legal orders and modes of production. 3

\footnotetext{
1 I would like to thank Claire Vergerio, Richard Drayton and Hamish Scott for their comments on earlier drafts and helpful conversations.

2 For classic early modern diplomatic histories, see Numelin 1950; van der Essen 1953; Mattingly 1955; Carter 1966; Anderson 1993; Davis Cross 2007. For histories of ambassadorial immunity, see Adair 1929; Frey and Frey 1999. For classic IR texts that build on these sources for an English School history of international law, see Bull 1977; Watson 1982; Bull and Watson 1984; Keene 2002; Buzan and Lawson 2015.

3 Roosen's (1976, p. 66) complaint about the lack of work on the social bases of diplomats remains valid, in spite of some exceptions in Bély 1999 and Scott 2007. See Teschke 2003 for a Marxist critique of IR's standard narrative of the emergence of the system of sovereign states after Westphalia.
} 
However, diplomatic history has recently experienced a certain renewal by expanding its use of sources, exploring broader aspects of the function and consequences of diplomacy, and considering a larger variety of actors qualifying as diplomats.4 This has led to studies of the individual lives of diplomats - and of the wider social and geographical implications of their functions - that emphasise the cultural, religious, aesthetic, and linguistic aspects of early modern politics. 5 This new literature is a welcome addition to the narrower repertoire of the classic studies, even if it continues to lack direct engagement with the socio-economic context of diplomacy.

One would expect the study of extraterritoriality in the early modern period to benefit from this new wave of diplomatic history. However, in contrast to recent developments in international legal history, some exemplified by this volume, few historians of diplomacy or international relations engage with the issue of extraterritoriality. And when they do so, they are invariably based to a significant degree upon Adair's 1929 work on early modern ambassadorial immunities entitled The Exterritoriality of Ambassadors in the Sixteenth and Seventeenth Centuries.6

This chapter does not seek to explain early modern extraterritoriality fully or to revisit its history as ambassadorial privileges. Instead, it seeks to inaugurate discussion of a broader research project by rethinking early modern extraterritoriality in relation to a fundamental concurring event: the transition to capitalism. This broader project, developed in further detail elsewhere, aims to enrich diplomatic history's institutional and cultural perspective through a more productive engagement with legal histories of extraterritoriality and historical materialist approaches.7 Specifically, Political Marxism is used as an approach that can reveal some of the underlying socio-economic causes of shifts in diplomatic practice and personnel.8

\footnotetext{
4 Although the term 'diplomat', as we understand it today, only appears in the late eighteenth century, the occupation of diplomacy refers here more broadly to the early modern use of envoys, messengers, representatives, consuls, nuncios, and legates, i.e. ambassadors of various statuses and designations placed on missions by the sovereign, prince, or other jurisdictional entity (e.g. a pope, lord, city, or company) they represented.

5 For new approaches to the history of diplomacy see Bély 1999; Frigo 2000; Bély 2007; Scott 2007; Watkins 2008; Hampton 2009; Adams and Cox 2011; Jacobsen 2011; Sowerby and Hennings 2017; Fedele 2017. For a short general overview of recent developments in early modern diplomatic history, see Dover and Scott 2015.

6 An exception is Napolitano 2012. Kaplan 2002 discusses extraterritoriality but does not add much to work by Adair and Mattingly. More generally, for Mattingly (1955, pp. 257), Adair is 'not only a thorough treatment of its subject, making conscientious use of concrete historical instances to illuminate the writings of the jurists, but a good general introduction to the later Renaissance literature about the international law of diplomacy'. For Anderson, (1993, p. 295), Adair 'remains the standard work on an important topic'. For Dover and Scott (2015, p. 693), 'the standard work remains E. R. Adair'.

$7 \mathrm{Pal}$, forthcoming.

8 'Political Marxism' was a label attributed in the 1980s to the work of social and political historians Robert Brenner and Ellen Meiksins Wood. The Brenner debate on the transition to capitalism has known various iterations since the original collection in Aston and Philpin 1985. It has most recently generated rich debates between different approaches to Political Marxism, some more structural and Brennerite (e.g. Post 2013) and others more radically historicist (e.g. Knafo and Teschke 2017). Such debates have also produced rich interpretations of Trotsky's theory of Uneven and Combined Development (UCD) following its renewal in IR by Rosenberg 2013 and most recently Anievas and Matin 2016. For a critique of the UCD approach to international historical sociology that chimes with the
} 
It is important to enter some caveats here. With its focus on Europe, this chapter perpetuates the geographical or empirical Eurocentrism found in many studies of diplomatic history. The most significant part of the 'decentring Europe' agenda undoubtedly consists in studying the development of international law and international relations outside Europe. However, Eurocentrism does not consist solely of a certain geographical focus. 9 Rather, challenging the myth of a supposedly linear, homogeneous, and normatively progressive development of European institutions is essential to the writing of non-Eurocentric history. In other words, it is also necessary to study the evolution of legal, political, and economic institutions in Europe so as to contribute to a critical non-Eurocentric historiography. Revisiting the early modern history of extraterritoriality through the angle of the transition to capitalism in England is, I argue, one such contribution. It breaks down the elitist and institutionally narrow history of diplomacy by focusing on class and other socioeconomic factors, and provides a more 'entangled' and contested - rather than linear and homogeneous - history of the early modern period. 10

Section one of this chapter presents the classic narrative according to which extraterritoriality shaped modern territoriality through the rise of permanent embassies and ambassadorial immunity, marking the shift from personal to territorial concepts of sovereignty. It focuses on the issue of embassy chapels as a catalyst for this shift. New diplomatic histories offer opportunities to go beyond this linear and homogeneous story of European diplomatic practices. Specifically, for example, Napolitano's work explores the way in which the reign of Louis XIV (1643-1715) developed specific practices of extraterritoriality and territorialisation through a range of architectural, artistic, and cultural means. Nevertheless, significant parts of the story are not explored.

Section two pushes the story beyond Napolitano's account by considering the socio-economic context within which these developments unfolded, examining the social property relations that underlay shifts in diplomatic practices. Leading diplomatic regimes, in particular France and Spain, became more aristocratic from the late seventeenth century onward. This led to significant changes in prevailing diplomatic practices. Such practices differed in many ways from diplomatic practices in England, where members of parliament (MP) diplomats were used during the same period.

The chapter concludes by rejecting the narrative that ties early modern extraterritoriality strictly to embassy chapels, and, more generally, to religious conflicts. It points instead to the importance of agrarian capitalist social property relations and class dynamics for the shaping of different doctrines of extraterritoriality in the early modern period, one led by France and Spain and another led by England and the Dutch Republic. This argument highlights the need for further in-depth

present research, see Teschke 2014, who laments the focus on agency and historical specificity and is critical of a theoretical framework that purports to explain a priori largescale historical change. See Pal 2018 (forthcoming) for a critique of UCD in Anievas and Nişancioğlu 2014 in relation to the history of international law.

9 For a discussion of this type of empirical Eurocentrism (in which studies reaching beyond Europe fail to dislodge the methodological and normative implications of Eurocentrism), see Bhambra 2007 and Go and Lawson 2017, p. 8.

10 For an argument for a global historical sociology of 'entanglements', see Go and Lawson 2017 , p. 4. For studies of relations between European and non-European early modern forms of extraterritoriality, see Benton 2010; Benton and Ross 2013; Belmessous 2012. 
studies exploring the social property relations underlying early modern practices of diplomacy and extraterritoriality.

\section{Diplomatic history and early modern extraterritoriality}

Legal histories of extraterritoriality have focused largely upon its various manifestations in the 'semi-sovereign' states and colonies of the nineteenth century, when it was used by the great powers - France, Britain, Germany, the United States, Russia - as a powerful tool of imperial domination.11 Indeed, it was during the nineteenth century that the world witnessed the emergence and widespread usage of the term 'extraterritoriality'. In effect, legal scholarship tends to be concerned chiefly with the global and structuring juridical manifestations and effects of this practice. Hence the focus on the establishment of extraterritorial courts and unequal treaties constituting the international legal order and legal subjects of the late nineteenth century. When considering the early modern context, legal scholarship remains concerned with the wider history of jurisdictional privileges and exemptions attributed to individuals other than diplomats and envoys, such as chartered companies, consuls, merchants, and religious officials not necessarily directly representing or on business for their sovereign. 12

Nevertheless, in spite of the recent revival of scholarship in international legal history, early modern extraterritoriality has tended to be a neglected area of study.13 In contrast, IR historiography has shown more concern for early modern extraterritoriality. However, this concern has remained in the context of the European shaping of the profession of modern diplomacy and mostly in relation to the development of the modern state encapsulated by the slow establishment of ambassadorial privileges over more or less three hundred years, from the Venetians' first permanent embassies in the early fifteenth century to their generalization across Europe by the mid-eighteenth century. For Bull, the 'legal recognition of the extraterritoriality of ambassadors by foreign services in the period of Louis XIV' is the most important stage of the mid- to late seventeenth century in the institutionalisation of modern diplomatic relations. 14

More specifically, Hugo Grotius is credited by Adair with coining the term 'quasi extra territorium':15

an Exception should be made in Favour of Embassadors, who, as they are, by a Sort of Fiction, taken for the very Persons whom they represent ... so may

11 Horowitz 2004; Kayaoğlu 2010; Ruskola 2013; Cassel 2012; Özsu 2015. See the chapters by Kate Miles, Richard S. Horowitz, Mai Taha, and Ntina Tzouvala in this volume. 12 Scholars such as Kassan 1935 and Tait Slys 2014 go further historically by exploring the history of extraterritoriality in ancient times. Similarly, from the diplomatic history tradition, Numelin (1950, p. 297) discusses the presence of 'extraterritorial rights and other diplomatic privileges' in the Amphictyonic Councils of the Hellenic world of the fourth and fifth centuries BC. He uses the expression 'exterritorial or diplomatic privileges' (1950, p. 310). 13 For an exception that considers early modern extraterritoriality in the cases of sixteenthcentury chartered companies, see the chapter by Kate Miles in this volume.

14 Bull 1977, p. 160. Other stages are 'the emergence of resident embassies in Italy in the fifteenth century, spreading throughout Europe as a whole in the sixteenth' and the 'emergence of the diplomatic corps in the eighteenth century'.

15 Adair 1929, pp. 5-6 (citing Grotius, De Jure Belli ac Pacis (1646 edition): 'fictione simile constituerentur quasi extra territorium'). 
they by the same kind of Fiction be imagined to be out of the Territories of the Potentate, to whom they are sent. Hence it is, that they are not subject to the Laws of the Country, where they reside. 16

Yet Adair emphasises that extraterritoriality emerged as a practice based on personal law, and was only later discussed by legal theorists and regulated by law in the seventeenth century.17 Thus, if the English form appears much later, the idea is far older. Various early modern extraterritorial practices have been compared or considered to be identifiable under the banner of the idea of extraterritoriality, such as capitulations, franchises de quartier, privileges, immunities, and disputatio. For example, as Napolitano argues, "[w]hile he does not use the term "extraterritorial" Ayrault's concept is fundamentally the same insofar as the ambassador carries with him the laws of his homeland'.18 Fundamentally, for Adair, the idea can be traced back to the recognition of the 'personal immunity of an ambassador and the sacredness of his functions', based on contractual Roman law, and medieval legal texts including the rights of ambassadors such as Castille's Siete Partidas.19

Scholars following Adair have largely adopted this view. Mattingly writes that the 'modern formulation', 'doctrine', or 'theory' of extraterritoriality is said to emerge over the eighteenth century, marking the shift from a personal to a territorial conception of sovereignty. Similarly, for Napolitano, 'the most fundamental transformation of sixteenth-century diplomacy was the establishment of the residential embassy in capital cities throughout Europe', where 'the immunities previously associated with the diplomat himself took on built form, representing a shift from a personal to a territorial model of embassy'.20

Adair's argument implies a linear view of the transport of authority between key political and legal actors. This linearity is expressed in the shift from an idea of a transport of authority attached to the person of the diplomat - who represents the sovereign - to a doctrine of transport of authority attached to the territory of the embassy - which represents the kingdom or state. In other words, the modern doctrine of extraterritoriality, according to diplomatic history, is the result of the shift from the diplomat (the personal) to the embassy (the territorial).

In particular, embassy chapels are considered to have played a significant role, not only as spaces of religious dissent, but also as 'probably the largest single factor in preparing men's minds to accept [the] extraordinary fiction' of extraterritoriality. 21 They are said to have followed the emerging practice of semi-permanent representatives to foreign courts initiated by the Renaissance Italian city-states in the 1520s.22 In the seventeenth century, capital cities in England and the Dutch Republic

16 Grotius 2005, p. 912 (emphasis added).

17 This point is emphasised in three reviews by Grafton Wilson 1930, Stowell 1930, Ronalds 1930.

18 Napolitano 2012, p. 59. Pierre Ayrault was a sixteenth-century French jurist and humanist (1516-1601). For an in-depth study of his contribution to the relation between early modern diplomatic practice and the construction of international legal orders, see Fedele 2016.

19 Adair 1929, p. 6.

20 Napolitano 2012, pp. 60-61. For other formulations linking the shift from the personal to the territorial through the fiction of extraterritoriality, see Buckley 1966, pp. 350-51.

21 Mattingly 1955, p. 242.

22 In the 1550s embassy chapels operated in London and other cities. They grew in number from 1600, and increased further following the negotiations of the Thirty Years' War. By the 1680s, most 'national' capitals tolerated them, as well as Vienna (an imperial capital) and 
were at the forefront of tolerating the largest number of embassy chapels. Moreover, they were also the first to legislate extraterritoriality in terms of ambassadorial immunity - the Dutch in 1651 and the English in 1709.23

Before embassy chapels became accepted and regulated in the late seventeenth and eighteenth centuries, diplomatic immunities 'did not extend to violations of the host country's fundamental laws' such as heresy.24 Providing ambassadors with the possibility of practising an outwardly 'heretical' faith in their chapels was therefore highly controversial, and constituted an opportunity for rulers to foment conflict with their rivals, forge alliances, and stir up religious strife.

Embassy chapels thus represent one of the crucial means through which territorialisation occurred in western Europe. They illustrate the social conflicts at the origins of the modern doctrine of extraterritoriality. They disturb the idea of the personal transport of authority that once prevailed as a principle of ambassadorial immunity.

Yet the story might not be as neat and tidy as classic diplomatic history tells it. For one, Dover and Scott acknowledge the problematic 'tidiness and linearity' of the trajectories in Mattingly's work and in the studies that it has influenced regarding embassy chapels.25 Crucially, Napolitano's work-more in tune with the new diplomatic history turn - provides an account of jurisdictional complexity and the variety of political representations of sovereignty and privilege among a myriad of early modern actors. Her primary research focuses on the late seventeenth century 'at the palace and in the urban environs of Palazzo Farnese in the first decades of Louis XIV's personal reign'.26 She argues that 'a variety of media including architectural projects, urban claims, ceremonial displays, and city views' shaped by France's envoys in Rome 'were visible and material manifestations of France's extraterritorial presence in the city'.27 Moreover, she develops a concept of 'spatial fiction of immunity' which applies 'Grotius's characterization of ambassadorial immunity as a "double fiction" to the built environment'. By being linked, these conceptions serve 'both to represent sovereignty but also to embody it'.28

Based on accounts of the struggles within the French court and its Roman embassy over absolutist conceptions of sovereignty and territory, Napolitano shows that extraterritoriality was becoming an 'exercise of political leverage' and a means to assert the monarchy's 'territorializing ambitions'.29 Furthermore, the development of extraterritoriality as permanent ambassadorial diplomacy is due, in her view, to the pragmatic ideas and desire for power of Louis XIV and his predecessors (e.g. Richelieu, Mazarin) who pushed for the assertion of their sovereign rights abroad. In other words, extraterritoriality is considered in this case to be the outcome of a French

self-governing states like Venice. London counted eight or nine, The Hague counted seven, Paris four, and the Dutch sponsored twelve in various capitals. They were also found in various capitals of the Holy Roman Empire. See Kaplan 2002, p. 343.

23 Kaplan 2002, p. 344. However, embassy chapels were initially only tolerated in France and England, even though their presence augmented in the Dutch Republic during the seventeenth century. See Mattingly 1955, p. 243.

24 Kaplan 2002, p. 343.

25 Dover and Scott 2015, p. 665.

26 Napolitano 2012, p. 28.

27 Ibid. p. ii.

28 Ibid. p. 197.

29 Ibid. p. 36. 
elitist and royalist discourse and practice, rather than the outcome of pan-European religious conflicts and their gradual toleration as illustrated by the rise of embassy chapels. 30

Napolitano's work thus enriches the classic diplomatic history's linear narrative of the shift from personal to territorial, or from the idea to the doctrine of extraterritoriality. It does so by focusing on Louis XIV's reign and its dominance over European diplomacy, and by pointing to the mutual imbrication of the personal and territorial during this period through a closer reading of Grotius. Her work chimes with more recent studies on the ancien régime dynamics of seventeenth- and eighteenth-century European diplomacy and the role of Louis XIV in maintaining this order through increased use of the aristocracy in diplomatic positions.31

Moreover, to take this analysis further and consider the socio-economic context of these shifts, the following section adopts an approach grounded in Marxist historical sociology to discuss the social origins of diplomats and the evolution of the occupation as it faced the structural changes of agrarian capitalism. This involves a more critical examination of the ambassadorial basis of the so-called 'modern' doctrine of extraterritoriality and the class dynamics inherent in this practice.

\section{Extraterritoriality and the transition to capitalism in England}

Diplomatic history's focus on personal law in the early modern period is crucial and largely uncontroversial. It serves to characterize ambassadorial immunity and the idea preceding the doctrine of extraterritoriality. The discussion here does not intend to fully explore or critically analyse the early modern predominance of personal law, its more imbricated relation to territoriality during the early modern period, or the gradual shift to a territorial conception of sovereignty characterizing nineteenthcentury modernity. However, it does question why studies of early modern diplomacy ignore the socio-economic causes of the relation between personal and territorial forms of sovereignty. If changes in the socio-economic functions and contributions of individual diplomats have become a more important object of study, their social origins and class dynamics still remain neglected. 32

The doctrine of extraterritoriality, celebrated by IR and diplomatic scholarship, is crucial because it allows sovereignty to be divided, extended, and imposed over and above existing jurisdictional rights. The shift to territoriality is of

30 'The decisions around the rental, including its location, size, urban situation, and the rights associated with proprietorship, all had lasting effects on the exercise of French extraterritoriality in Rome ... the demarcation of the French quarter during this period predated any formal discourse on the rights of extraterritoriality. In this sense, the early years of French embassy in Rome may be considered a seedbed for developing thought on the architectural and urban rights associated with embassy.' Napolitano 2012, p. 97 (emphasis added). 'My primary focus has been on the development of a discourse associated with the jurisdictional rights of French embassy, which emerged, in part, from the larger effort by Louis XIV to exercise personal control over every aspect of his foreign policy and diplomatic engagement. This discourse manifested as a unique form of urban authorship.' Napolitano 2012 , p. 147.

31 Bély 1999; Scott 2007.

32 The English/British and French diplomatic services have been the most studied in terms of individual diplomats. For general accounts with an analysis of social origins, see Roosen 1976; Bély 1999; Scott 2007. For accounts of English and British diplomatic services, see Horn 1961; Lachs 1965; Carter, 1966; Bell 1990; Black 2001; Dyson, 2003; Jettot 2010. 
paramount historiographical importance because it is supposed to signal that the division, extension, and imposition of sovereign rights is part of a progressive cause for the development of professional diplomacy, the balance of power, and a system of formally equal sovereign states. It thus serves to justify in classic narratives the practices of early modern European empires as progressive, which are eventually cast in nineteenth-century extraterritorial practices as pillars of colonial policy. Returning to the social origins of these practices in the early modern context is therefore crucial to understanding their role in the nineteenth century.

To recap, in the early modern European context, sovereignty was mostly determined by personal, dynastic, and religious rules and actors far beyond the supposedly watershed moment attributed to the Westphalia treaties.33 For Political Marxists, this means that the shift to capitalist modernity characterized by the spread of territorial sovereignty occurred in the nineteenth century, once European nationstates emerge and co-exist politically and formally as equals able to compete more or less freely in a world economy and share between themselves the spoils of imperialism.34 For critical international law scholarship, the late nineteenth century also marks the establishment of international law as a profession and an institutional regime of conferences and decision-making bodies, ideal for justifying and administering imperial conquests as a 'civilising mission'. 35

Unequal international relations and processes of accumulation no less determined the early modern period, but these were not necessarily capitalist. This period witnessed various modes of accumulation (e.g. geopolitical, jurisdictional, primitive), and various processes of transition from feudalism to capitalism. However, some local transitions to capitalism occurred in the early modern period. The rich and ongoing debate about where and how the transitions from feudalism in Europe occurred and how they incorporated, extended, and relied on non-European labour and resources cannot be rehearsed fully here. 36 This chapter thus limits itself to the impact on diplomacy of the transition to agrarian capitalism in the English early modern countryside. Although it cannot do full justice to this question, it reveals some important divergences between France and England in regard to their strategies of territorialisation, as well as their selection and use of diplomats.

\footnotetext{
33 What has been called the 'Westphalian imaginary' implies harking back to 1648 as the gateway date to modernity or assuming the Westphalian system as a widely accepted marker, however imprecise that may be. Both are used to mark the significant shift to modern conceptions of territoriality. See Windler 2017 pp. 261-262 for a recent critique of Westphalia as a 'relevant epochal boundary' in diplomatic history. For a critique of enduring statecentrism and the Westphalian fetish in international law, even in postcolonial histories, see Koskenniemi 2016. Although IR has since the 1990s produced many analyses deeply critical of the Westphalian myth (e.g. Osiander 2001; Teschke 2003), it remains a heavily encased benchmark in the non-historically inclined areas of the discipline and in most of its pedagogical material, as well as in other disciplines in the social sciences which uncritically reproduce this myth.

34 Rosenberg 1994; Teschke 1998; Wood 2003. For a non-Marxist perspective, see Buzan and Lawson 2015 (arguing for a revised research programme looking at the nineteenth century as defining the shift to modern international relations).

35 Koskenniemi 2001. For a more nuanced and Marxist analysis of the standard of civilization, see Tzouvala 2019 (forthcoming).

36 For a recent review and argument of this debate, see Anievas and Nişancioğlu 2014 and a symposium on their work in Historical Materialism $(2018,26.3)$.
} 
On the one hand, as discussed in section one, the French regime experimented with new diplomatic strategies in its Roman embassy, thus signalling a mix of personal and territorial conceptions of sovereignty. On the other hand, large-scale structural changes had been occurring for some time in the relations between lords, farmers (yeomen), and peasants in the English countryside. These changes occurred most notably through processes of wage-dependency, leasing, enclosures, dispossession, and depopulation, marking the establishment of capitalist social property relations in a context of shifting class strategies and related social-structural reconfigurations. 37

Social and economic historians agree that the 1600s saw the most significant changes in England's transformation from an open field to an enclosed country, that is, the classic transition phase. By 1700, 70 percent of cultivable land in England is said to have been enclosed, and three-fifths of the English population had primarily become wage-workers (though statistics for this period ought to be treated with caution). 38 Moreover, in 1688, 40 percent of England's population relied on nonagricultural occupations, marking its divergence from other European societies such as France. Based on primary research on enclosure acts in Kent and work by Whittle and Mate on other regions in England, Dimmock argues that the long fifteenth century (the 1370s to the 1530s) produced the most important social changes for the shift to agrarian capitalism. Specifically, this earlier period produced the structural changes and the logic necessary for the more visible changes that occurred after the $1520 \mathrm{~s}$, that is, in the classic transition phase of the seventeenth century. In sum, the fifteenth and sixteenth centuries saw a restructuring of England's social property relations, involving cases of forced depopulation on a scale not seen since the Norman conquests of the eleventh century. 39

If, as Dimmock argues, the long fifteenth century is important in its structural changes to the property relations between lords, farmers, and peasants, did the latter have an effect on diplomatic practice? Before considering this in detail, it is necessary to provide a general sense of the class dynamics of diplomacy. Diplomacy across Europe, particularly in England, remained personal, in the sense of being dependent upon the person of the sovereign and the person of the diplomat.40 In England, merchants as well as members of the clergy were often mobilised to represent the interests of the sovereign or communicate messages.41 If the role of the clergy gradually diminished, that of merchants increased later in the seventeenth century. 42

Across Europe, diplomats and other representatives acted not only at the behest of sovereigns, but also of cities and companies.43 However, this changed at the end of the seventeenth century as permanent embassies became more widespread after the 1648 Westphalian treaties.44 England and other northern and eastern kingdoms lagged behind Spain and France, which were the first to copy the Italian city-states' practice of establishing and maintaining permanent embassies. These permanent embassies were established between the Italian city-states by the 1450s, and

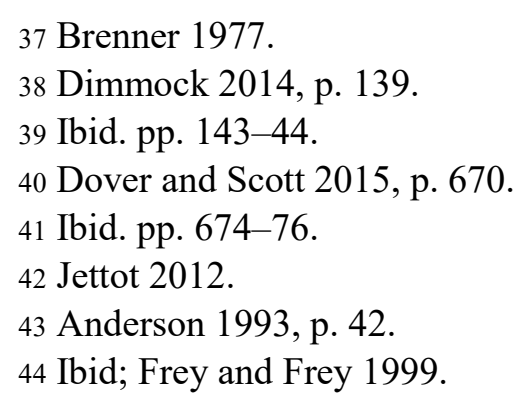


Venetians are said to have had training in diplomacy from their contacts in the eastern Mediterranean.45 Regular and permanent embassies gradually came to be occupied by a more socially homogeneous (i.e. aristocratic) and self-conscious diplomatic corps. This replaced the temporary nature of the socially complex patchwork of diplomatic actors active up to the late seventeenth and early eighteenth centuries.46

Thus, from the late seventeenth century, diplomats were more likely to be chosen from the higher social elite and based upon family connections, except in England and the Dutch Republic.47 Moreover, the English and Dutch were at the forefront of tolerating embassy chapels in the seventeenth century, shaping the socalled 'modern' doctrine of extraterritoriality, but they lagged behind Spain and France with respect to permanent embassies. This raises the question of how we ought to explain the English and Dutch exceptions in regard to the social origins of diplomats. A significant part of the answer to our question lies in specific social structures and social property relations.

The English and Dutch cases are somewhat exceptional in that they do not follow the pattern of an emergent aristocratic diplomacy, are distinguished by a different process of capitalist and proto-capitalist development, and are at the forefront of legislation for ambassadorial immunity. Different reviewers of Adair noted his point that in "England and the United Provinces "the peculiar immunities of an ambassador were protected by law"; "elsewhere in Europe the royal prerogative alone could protect foreign ministers'.48 This bolsters the view that French diplomats could count on the authority of their sovereign, whereas English diplomats had to operate in a much more unstable institutional climate. 49 Their case therefore merits closer attention, though it will only be possible to discuss England here, and in particular whether agrarian capitalism can explain the lack of aristocratisation of England's diplomatic missions.

Jettot has explored in detail the rise of MPs in the foreign service of England in the period between 1660 and 1702.50 Previously, an emerging gentry had been accessing political posts since the late fifteenth century, and constituted a large number of diplomatic agents at least since the sixteenth century.51 The English peerage was traditionally used for the most prestigious posts.52 However, they did so reluctantly. Diplomatic missions were costly, dangerous, tiresome, and mostly used to

45 Mattingly, 1955, p. 87; Numelin 1950, p. 306. See Fusaro 2015 for an analysis of the important diplomatic and commercial links between England and Venice.

46 Scott 2007.

47 Dover and Scott 2015, p. 685; Anderson 1993, p. 80.

48 Ronalds 1930, p. 117. See also Stowell 1930, p. 413.

49 Jettot 2012, p. 16.

50 Jettot 2012.

${ }_{51}$ For the role of the gentry in political posts, see Dimmock 2019. For its role in diplomatic posts, see Giry-Deloison 1987, p. 214; Carter 1966, pp. 284-285; Dyson 2003, pp. 26-30; Lachs 1965, p. 54.

52 English aristocratic presence in diplomatic missions was higher than in other European contexts before the 1660s. But in both cases, the percentage of aristocrats was very low. See Giry-Deloison 1987 for a comparative study of French and English diplomatic posts from 1485 to 1520 . In England the aristocracy constituted 17 percent of diplomats. The numbers are even lower in France, where the aristocracy accounted for 9 percent of diplomats during this period. In both cases, the presence of roturiers very largely dominated diplomatic missions. But England remained nevertheless more adept at selecting lords to represent their sovereign. 
assert oneself and gain favour with the sovereign for securing a post at home. In this sense, the transition to agrarian capitalism and the successive waves of enclosures in England helped to provide sovereigns with a rising gentry willing to serve as diplomatic agents and make up for the nobility's lack of diplomatic engagement.53 MPs chosen as diplomats 54 in the late seventeenth century came not only from the propertied elite such as the younger sons of lords, but also from the higher gentry, professionals such as lawyers, doctors, and teachers, and in some cases from rich merchants.55 A diplomatic mission ensured their higher social position, and could be a remarkable social ascension. It can be ventured that the structural changes of the long fifteenth century in the advent of agrarian capitalism offered financial opportunities and social standing to a part of the male population and made them more amenable to fulfill diplomatic missions. These men constituted a different foreign service than those developing on the European continent, and this was confirmed by their role in parliamentary offices come the later seventeenth century.

MP missions were generally situated between lords, who were charged with extraordinary embassies, and other envoys such as merchants and lawyers charged with lower-order tasks as residents or consuls. MP diplomats were loyal to the king and to the commons, and were to defend a harmonious and peaceful vision of the kingdom to outsiders, so as to quiet the rumours of a latent civil war.56 They were seen as the living symbols of the king-in-parliament, or crown-in-parliament, a cornerstone of the specific development of the English state, enabling the class alliances that favoured the development of agrarian capitalism. 57

The use of these diplomats had other important implications. They were often accused of corruption, francophilia, 58 'crypto-catholicism', and of neglecting their constituencies. Yet they remained closely tied to their local and personal interests.59 Crucially, they returned from the continent with new practices and forms of knowledge that they could diffuse to wider social contexts, and they represented the interests of various groups (merchants, electors, Huguenots), which the king had to take into account when formulating diplomatic strategies.60 For Jettot this parliamentary legacy played a role in expectations that later British imperial policies

53 It is also important to note that the English higher nobility in the early modern period was already significantly lower in numbers and authority than its French equivalent class. See Comninel 2000.

54 Between 1558 and 1603, forty-three 'MP-diplomats' were in operation, signalling a precocious presence of parliamentarians in the external affairs of their sovereign. Between 1660 and 1702, there were fifty-three MP-diplomats, a third of England's diplomatic personnel, though from 1685 their external role was reduced significantly. In the early eighteenth century, biographical data is only available for thirty-eight MP-diplomats, of which sixteen belonged to the House of Lords and fifteen to the House of Commons. Finally, between 1715 and 1754, Jettot finds fifty-six MP-diplomats. See Jettot 2012, p. 21.

55 Jettot 2012, pp. 26-28.

56 Jettot 2012, p. 30.

57 Ibid. p. 537; Wood 1992.

58 Charles II developed a pro-French diplomacy strategy, linked to a military French-Catholic alliance, which then backfired because of financial losses following the defeat against the Dutch Republic. See Jettot 2012, p. 536.

59 Ibid. pp. 31, 536, 537.

60 Ibid. p. 540. 
would be influenced to a greater degree by 'popular' interests and by the legitimacy of the commons, however much these expectations were to be disappointed.61

In the meantime, the reign of Louis XIV led the way for the shift to an aristocratic corps diplomatique, focused on etiquette, protocol, and ceremonial practices that maintained the order of the ancien régime in the European political sphere until at least the end of the eighteenth century.62 Dover and Scott qualify this new 'European network of resident diplomats' as the 'aggregate of its court societies'.63 Louis XIV was also instrumental in shifting the lingua franca of diplomacy from Latin to French, though Latin remained in use.64 How the social property relations of France's various regions and parlements put pressure on Louis XIV's regime to collaborate with the aristocracy, and deploy a more aristocratic diplomatic corps to sustain an old regime Europe, remains to be explored.65 But ignoring these specificities and socio-economic conditions undoubtedly obscures the history of ambassadorial privileges and the emergence of extraterritorial principles in the early modern period. In particular, it obscures the ways in which agrarian capitalism explains the lack of aristocratisation of England's diplomatic missions, and thus its different approach and strategy to the transport of its authority.

\section{Conclusion}

There are three significant implications of this initial foray into the relations between early modern extraterritoriality, diplomacy, and the transition to capitalism. First, classic diplomatic history tends to adopt a linear and homogeneous view of the shift from personal to territorial sovereignty that is overly focused on state institutions and the classical legal theory canon. This contributes to IR scholarship's tendency to ignore the role of capitalism as a mode of production with political dimensions and consequences, and more generally the role of social property relations in shaping international legal actors and orders.

Second, diplomatic history assumes that extraterritoriality is a strictly political or legal process, driven by religious conflicts and eventually morphing into a discourse of rights adopted by the elite and developed as a theoretical fiction by leading legal theorists. Following Adair, it is said to have emerged 'gradually' and 'unconsciously' from a notion of personal transport of authority.66 This account remains limited in terms of new studies in diplomatic history focused on cultural and aesthetic dimensions, as well as being divorced from socio-economic contexts and social property relations.

Third, the context discussed in this chapter's second section illuminates the role of such social property relations, helping us to distinguish between different types of shifts and overlapping personal and territorial sovereignties based upon different

61Ibid.

62 Bély 1999.

63 Dover and Scott 2015, p. 686. 64 Numelin 1950, p. 308. Before Latin, Babylonian was the diplomatic language across the ancient Near East.

65 On the maintenance of ancien régime Europe and the necessary collaboration between Louis XIV and France's nobilities in order to sustain a semblance of 'absolutism', see Parker 1996 and Beik 1985.

66 Adair 1929, pp. 9-12. 
strategies of territorialisation and social origins of diplomats, specifically in the cases of France and England.

In sum, my argument disturbs the claim that embassy chapels - and the rise of ambassadorial immunities more generally_were 'the largest single factor in preparing men's minds to accept [the] extraordinary fiction' of extraterritoriality. In effect, embassy chapels and the supposed push for religious freedom and toleration by ambassadors are not the most important manifestation of early modern extraterritoriality.

Instead, the practices of England and the Dutch Republic diverge from those of France and Spain in their socio-economic structures and political strategies, creating different processes of territorialisation - and thus of extraterritoriality. If England and the Dutch Republic led the way in terms of embassy chapels, they contrasted with old regime Europe, which instead was characterised by the development of permanent embassies and the aristocratic basis of the diplomatic corps. The different patterns of early modern extraterritoriality therefore reflect the different patterns of social property relations in western Europe's competing empires. Needless to say, this historical argument remains preliminary and points to the need for broader research projects on the historical sociology of early modern extraterritoriality and jurisdictional practices.

\section{Bibliography}

Adair, E. R. (1929), The Exterritoriality of Ambassadors in the Sixteenth and Seventeenth Centuries (New York: Longmans, Green and Co.).

Adams, Robyn and Rosanna Cox (eds) (2011), Diplomacy and Early Modern Culture (Basingstoke: Palgrave).

Anderson, M. S. (1993), The Rise of Modern Diplomacy 1450-1919 (New York: Longman).

Anievas, Alexander and Kerem Nişancioğlu (2014), How the West Came to Rule: The Geopolitical Origins of Capitalism (London: Pluto).

Anievas, A. and Kamran Matin (eds) (2016), Historical Sociology and World History: Uneven and Combined Development over the Longue Durée (Lanham: Rowman and Littlefield).

Aston, T. H. and C. H. E. Philpin (eds) (1985), The Brenner Debate: Agrarian Class Structure and Economic Development in Pre-industrial Europe (Cambridge:

Cambridge University Press).

Beik, William (1985), Absolutism and Society in Seventeenth-Century France: State Power and Provincial Aristocracy in Languedoc (Cambridge: Cambridge University Press).

Bell, Gary M. (1990), A Handlist of British Diplomatic Representatives 1509-1688 (London: Royal Historical Society).

Belmessous, Saliha (ed) (2012), Native Claims: Indigenous Law against Empire 1500-1920 (Oxford: Oxford University Press). 
Bély, Lucien (1999), Espions et ambassadeurs au temps de Louis XIV (Paris: Fayard).

Bély, Lucien (2007), L'art de la paix en Europe: Naissance de la diplomatie moderne, XVIe-XVIIIe siècle (Paris: Presses Universitaires de France).

Benton, Lauren (2010), A Search for Sovereignty: Law and Geography in European Empires 1400-1900 (Cambridge: Cambridge University Press).

Benton, Lauren and R. J. Ross (eds) (2013), Legal Pluralism and Empires, 1500-1850 (New York: New York University Press).

Bhambra, Gurminder K. (2007), Rethinking Modernity: Postcolonialism and the Sociological Imagination (Houndmills: Palgrave Macmillan).

Black, Jeremy (2001), British Diplomats and Diplomacy, 1688-1800 (Liverpool: Liverpool University Press)

Brenner, Robert (1977), 'The Origins of Capitalist Development: A Critique of NeoSmithian Marxism’ 1(104) New Left Review 25.

Buckley, Margaret (1966), 'Origins of Diplomatic Immunity in England' 21 University of Miami Law Review 349.

Bull, Hedley (1977), The Anarchical Society: A Study of Order in World Politics (Columbia University Press).

Bull, Hedley and Adam Watson (eds) (1984), The Expansion of International Society (Oxford: Oxford University Press).

Buzan, Barry and George Lawson (2015), The Global Transformation: History, Modernity and the Making of International Relations (Cambridge: Cambridge University Press).

Carter, Charles Howard (1966), 'The Ambassadors of Early Modern Europe: Patterns of Diplomatic Representation in the Early 17th Century', in: Charles Howard Carter (ed), From the Renaissance to the Counter Reformation: Essays in Honour of Garrett Mattingly (New York: Random House), pp. 269-95.

Cassel, Pär Kristoffer (2012), Grounds of Judgment: Extraterritoriality and Imperial Power in Nineteenth-Century China and Japan (Oxford: Oxford University Press).

Comninel, George C. (2000), 'English Feudalism and the Origins of Capitalism' 27 Journal of Peasant Studies 1.

Davis Cross, Mai'a K. (2007), The European Diplomatic Corps: Diplomats and International Cooperation from Westphalia to Maastricht (Basingstoke: Palgrave Macmillan). 
Dimmock, Spencer (2014), The Origin of Capitalism in England 1400-1600 (Leiden: Brill).

Dimmock, Spencer (2019), 'Expropriation and the Political Origins of Agrarian Capitalism in England' in: Xavier Lafrance and Charles Post, Case Studies in the Origins of Capitalism (London: Palgrave Macmillan), pp. 39-62.

Dover, Paul and Hamish Scott (2015), 'The Growth of Diplomacy, c. 1450-1815', in: Hamish Scott (ed), The Oxford Handbook of Early Modern European History, 1350 1750, Volume II: Cultures and Power (Oxford: Oxford University Press), pp. 663-95.

Dyson, Tomas (2003) English Diplomatic Agents 1603-1688. D.Phil Modern History University of Oxford. Unpublished Thesis.

Fedele, Dante (2016), 'The Renewal of Early-Modern Scholarship on the Ambassador: Pierre Ayrault on Diplomatic Immunity' 18 Journal of the History of International Law 449.

Fedele, Dante (2017), Naissance de la diplomatie moderne (XIIIe-XVIIe siècles). L'ambassadeur au croisement du droit, de l'éthique et de la politique (Baden-Baden: Nomos Verlagsgesellschaft).

Frey, Linda S. and Marsha L. Frey (1999), The History of Diplomatic Immunity (Columbus: Ohio State University Press).

Frigo, Daniela (ed) (2000), Politics and Diplomacy in Early Modern Italy: Structure of Diplomatic Practice 1450-1800 (Cambridge: Cambridge University Press).

Fusaro, Maria (2015), Political Economies of Empire in the Early Modern Mediterranean: The Decline of Venice and the Rise of England 1450-1700 (Cambridge: Cambridge University Press)

Giry-Deloison, Charles (1987), 'Le personnel diplomatique au début du XVIe siècle. L'exemple des relations franco-anglaises de l'avènement d'Henry VII au camp du Drap d'Or (1485-1520)' 3 Journal des Savants 205.

Go, Julian and George Lawson (2017), 'For a Global Historical Sociology', in: Julian Go and George Lawson (eds), Global Historical Sociology (Cambridge: Cambridge University Press), pp. 1-34.

Grafton Wilson, George (1930), Review of Adair E. R. The Exterritoriality of Ambassadors in the Sixteenth and Seventeenth Centuries, 35 American Historical Review 592.

Grotius, Hugo (2005), The Rights of War and Peace, ed. Richard Tuck, vol. 2 (Indianapolis: Liberty Fund),

Hampton, Timothy (2009), Fictions of Embassy: Literature and Diplomacy in Early Modern Europe (Ithaca: Cornell University Press). 
Horn, David Bayne (1961), The British Diplomatic Service 1689-1789 (Oxford: Oxford University Press).

Horowitz, Richard S. (2004), 'International Law and State Transformation in China, Siam, and the Ottoman Empire during the Nineteenth Century' 15 Journal of World History 445.

Jacobsen, Helen (2011), Luxury and Power: The Material World of the Stuart Diplomat, 1660-1714 (Oxford: Oxford University Press).

Jettot, Stéphane (2012), Représenter le Roi ou la Nation? Les parlementaires dans la diplonatie anglaise 1660-1702 (Paris: Presses Universitaires de France).

Kaplan, Benjamin J. (2002), 'Diplomacy and Domestic Devotion: Embassy Chapels and the Toleration of Religious Dissent in Early Modern Europe' 6 Journal of Early Modern History 341.

Kassan, Shalom (1935), 'Extraterritorial Jurisdiction in the Ancient World' 29 American Journal of International Law 237.

Kayaoğlu, Turan (2010), Legal Imperialism: Sovereignty and Extraterritoriality in Japan, the Ottoman Empire, and China (Cambridge: Cambridge University Press).

Keene, Edward (2002), Beyond the Anarchical Society: Grotius, Colonialism and Order in World Politics (Cambridge: Cambridge University Press).

Knafo, Samuel and Benno Teschke (2017), 'The Rules of Reproduction of Capitalism: A Historicist Critique', Working Paper No. 12, University of Sussex Centre for Global Political Economy, online:

http://www.sussex.ac.uk/cgpe/research/workingpapers.

Koskenniemi, Martti (2001), The Gentle Civilizer of Nations: The Rise and Fall of International Law 1870-1960 (Cambridge: Cambridge University Press).

Koskenniemi, Martti (2016), 'Expanding Histories of International Law' 56 American Journal of Legal History 104.

Lachs, Phyllis S. (1965), The Diplomatic Corps under Charles II and James II (New Brunswick, New Jersey: Rutgers University Press).

Mattingly, Garrett (1955), Renaissance Diplomacy (Harmondsworth: Penguin).

Napolitano, Elena Cristina (2012), Prospects of Statecraft: Diplomacy, Territoriality, and the Vision of French Nationhood in Rome, 1660-1700. Ph.D. dissertation, University of Toronto.

Numelin, Ragnar (1950), The Beginnings of Diplomacy: A Sociological Study of Intertribal and international Relations (Oxford: Oxford University Press). 
Osiander, Andreas (2001), 'Sovereignty, International Relations, and the Westphalian Myth’ 55 International Organization 251.

Özsu, Umut (2015), Formalizing Displacement: International Law and Population Transfers (Oxford: Oxford University Press).

Pal, Maïa (forthcoming), Jurisdictional Accumulation: An Early Modern History of Law, Empires and Capital (Cambridge: Cambridge University Press).

Pal, Maïa (2018), “My Capitalism is Bigger than Yours!": Against Combining "How the West Came to Rule" with "The Origins of Capitalism"” 26.3 Historical Materialism 99.

Parker, David (1996), Class and State in Ancien Régime France: The Road to Modernity? (London: Routledge).

Post, Charles (2013), 'Capitalism, Laws of Motion and Social Relations of Production’ 21 Historical Materialism 71.

Ronalds, Francis R. (1930), Review of E. R. Adair The Exterritoriality of Ambassadors in the Sixteenth and Seventeenth Centuries, 2 Journal of Modern History 116

Roosen, William James (1976), The Age of Louis XIV: The Rise of Modern Diplomacy (Cambridge: Schenkman).

Rosenberg, Justin (1994), The Empire of Civil Society (London: Verso).

Rosenberg, Justin (2013), 'The 'Philosophical Premises' of Uneven and Combined Development' 39 Review of International Studies 569.

Ruskola, Teemu (2013), Legal Orientalism: China, the United States and Modern Law (Cambridge: Harvard University Press).

Scott, Hamish (2007), 'Diplomatic Culture in Old Regime Europe', in: Hamish Scott and Brendan Simms (eds), Cultures of Power in Europe during the Long Eighteenth Century (Cambridge: Cambridge University Press), pp. 58-85.

Sowerby, Tracey A. and Jan Hennings (eds) (2017), Practices of Diplomacy in the Early Modern World c. 1410-1800 (Abingdon: Routledge).

Stowell, Ellery C. (1930), Review of E. R. Adair The Exterritoriality of Ambassadors in the Sixteenth and Seventeenth Centuries, 24 American Journal of International Law 413.

Tait Slys, Mariya (2014), Exporting Legality: The Rise and Fall of Extraterritorial Jurisdiction in the Ottoman Empire and China (Geneva: Graduate Institute Publications), online: http://books.openedition.org/iheid/788.

Teschke, Benno (1998), 'Geopolitical Relations in the European Middle Ages: 
History and Theory' 52 International Organization 325.

Teschke, Benno (2003), The Myth of 1648: Class, Geopolitics, and the Making of Modern International Relations (London: Verso).

Teschke, Benno (2014), 'IR Theory, Historical Materialism, and the False Promise of International Historical Sociology’ 6 Spectrum: Journal of Global Studies 1.

Tzouvala, Ntina (2019, forthcoming), 'Civilisation', in: Jean d'Aspremont and Sahib Singh (eds), Concepts for International Law: Contributions to Disciplinary Thought (Cheltenham: Edward Elgar).

van der Essen, Léon (1953), La Diplomatie. Ses origines et son organisation jusqu'à la fin de l'Ancien Régime (Brussels: Editions P. D. L.)

Watkins, John (2008), 'Toward a New Diplomatic History of Medieval and Early Modern Europe' 38 Journal of Medieval and Early Modern Studies 1.

Watson, Adam (1982), Diplomacy: The Dialogue between States (London: Methuen).

Windler, Christian (2017) 'Afterword. From social status to sovereignty - practices of foreign relations from the Renaissance to the Sattelzeit', in: Tracey A. Sowerby \& Jan Hennings (eds), Practices of Diplomacy in the Early Modern World c.1410-1800 (Abingdon: Routledge), pp. 254-265

Wood, Ellen Meiksins (1992), The Pristine Culture of Capitalism: A Historical Essay on Old Regimes and Modern States (London: Verso).

Wood, Ellen Meiksins (2003), The Empire of Capital (London: Verso). 